\title{
Ratio of inner cell mass and trophoblastic cells in demi- and intact pig embryos
}

\author{
T. Tao, B. Reichelt and H. Niemann* \\ Institut für Tierzucht und Tierverhalten (FAL), Mariensee, 31535 Neustadt, Germany
}

\begin{abstract}
Pig morulae, early blastocysts and blastocysts were microsurgically bisected to produce zona-free demi-embryos or remained nonbisected with or without zona pellucida, and the presence of inner cell mass cells was determined using a differential fluorochrome staining technique. After $24 \mathrm{~h}$ of in vitro culture, all demi-embryos were classified into three categories, based on morphological criteria: 1, excellent; 2, fair; and 3, degenerated. The average number of total cells and inner cell mass cells in intact embryos cultured without zona pellucida for $24 \mathrm{~h}$ was higher $(P<0.05)$ than that for those with zona pellucida in morulae and early blastocysts. The percentage of demi-embryos without inner cell mass cells in these different morphological categories was $18.7 \%, 22.2 \%$ and $29.8 \%$ for morulae, respectively; $3.8 \%, 16.7 \%$ and $30.8 \%$ for early blastocysts, respectively; and $3.7 \%, 32.0 \%$ and $36.4 \%$ for blastocysts, respectively. The percentage of demi-embryos without inner cell mass cells was lower $(P<0.01)$ in demi-embryos classified in category 1 compared with category 3 in early blastocysts and in category $I$ compared with categories 2 and 3 in blastocysts. Significant differences in the total number of cells and the number of inner cell mass cells were apparent among the three morphological categories of demi-embryos derived from morulae, early blastocysts and blastocysts. The ratio of total cells to inner cell mass cells was similar among intact pig embryos and the different morphological categories of demiembryos derived from morulae, early blastocysts and blastocysts, with the exception of that between demi-blastocysts of category $I$ and the other groups. The loss of cells attributed to bisection was $25-30 \%$ in category 1 demi-embryos, and increased to $65 \%$ in category 3 demi-embryos. Demi-embryos in category 1 derived from early blastocysts and blastocysts experienced no loss of inner cell mass cells. It is concluded that (i) bisection of pig embryos can lead to a substantial proportion of demi-embryos lacking a functional inner cell mass, (ii) the proportion of total cells to inner cell mass cells is similar in demi-embryos and intact embryos, and (iii) the percentage of cell losses attributed to bisection increases with decreasing quality of demi-embryos. Collectively, these results indicate that the blastocyst is the optimal stage to obtain a maximum yield to viable pig demi-embryos.
\end{abstract}

\section{Introduction}

Bisection of bovine embryos has been applied widely under experimental and commercial conditions and pregnancy rates after nonsurgical transfer of demi-embryos are only about 5-10\% lower than those with nonbisected embryos (Williams et al., 1984; Baker and Shea, 1985; Takeda et al., 1986; Gray et al., 1991; Kippax et al., 1991). However, in pigs, bisection of preimplantation embryos is associated with a significant decrease in viability in vivo (Nagashima et al., 1988; Ash et al., 1989; Reichelt and Niemann, 1994). Several factors with profound effects on the viability of pig demi-embryos have been identified, such as the presence or absence of the zona peliucida, embryonic stage (Nagashima et al., 1988, 1989; Reichelt and Niemann, 1994), competition between demi-

* Correspondence.

Received 31 October 1994. embryos and nonbisected embryos (Ash et al., 1989), temperature during the bisection procedure (Stein-Stefani and Holtz, 1994), as well as experimental day, donor animal, boar, embryo quality, duration of the in vitro culture before bisection and size of the halves after bisection (Niemann and Reichelt, 1993). Morulae and blastocysts are appropriate stages to produce identical twin piglets, although with a low efficiency (Reichelt and Niemann, 1994). For an undisturbed embryonic development, a sufficient number of inner cell mass cells is essential. These can vary considerably according to the success of bisection.

This investigation, using the double dye technique for differential staining is the first to examine the effects of microsurgical bisection on inner cell mass and trophectoderm in pig demi-embryos. The staining procedure is based on an immunosurgical approach, in which, due to tight junctions in the outer cells of a zona-free embryo, diffusion of antibodies is 
prevented when the embryo is exposed to species-specific antiserum and the outer cells lyse after exposure to complement (Solter and Knowles, 1975). This technique was refined by using two different fluorochromes: propidium iodide for labelling trophectoderm nuclei and bisbenzimide to identify the nuclei of inner cell mass cells (Handyside and Hunter, 1984).

The purpose of this study was (i) to identify the percentage of demi-embryos, derived from pig morulae, early blastocysts and blastocysts, having a visible inner cell mass after culture in vitro for $24 \mathrm{~h}$, and (ii) to examine the number and ratio of total cells to inner cell mass cells in the three developmental stages. Since demi-embryos were cultured in vitro without a zona pellucida, the results were compared with those for zona pellucida-free and zona-enclosed nonbisected embryos. The results of these experiments are intended to verify the morphological classification of demi-embryos and determine to what extent these parameters contribute to the high losses observed after transfer of bisected pig embryos (Reichelt and Niemann, 1994).

\section{Materials and Methods}

\section{Experimental animals and embryos}

Forty-one prepubertal German Landrace gilts (185-243 days of age, $77-125 \mathrm{~kg}$ body mass) were used as donors on 12 experimental days. Superovulation was induced by i.m. injections of 1500 iu pregnant mares' serum gonadotrophin (PMSG; Intergonan, Vemie, Kempen) and $72 \mathrm{~h}$ later, an i.m. injection of 500 iu hCG (Ekluton, Vemie). Donors were mated twice to a fertile boar or artificially inseminated 24 and $48 \mathrm{~h}$ after administration of hCG. The day of the first mating or insemination was designated as day 0 . On days 4 and 5, donors were killed, uterine horns were flushed with $40 \mathrm{ml}$ PBS (Sigma, St Louis, MO) supplemented with $1 \%(\mathrm{v} / \mathrm{v})$ newborn calf serum (NBCS, Boehringer, Mannheim) and the morphology of the collected embryos was assessed (Niemann et al., 1983a; Niemann and Elsaesser, 1987). Subsequently, embryos classified as excellent or good in the morula, early blastocyst and blastocyst stage from the various donors were pooled and placed into $2 \mathrm{ml}$ PBS plus $10 \%(\mathrm{v} / \mathrm{v}) \mathrm{NBCS}$ at $37^{\circ} \mathrm{C}$ in a humidified atmosphere until they were randomly assigned to microsurgical bisection or control culture. Embryos with more than 8-10 compacted cells were considered as morulae. Early blastocysts possessed a small blastocoel which covered not more than $25 \%$ of the embryonic surface, while blastocysts were characterized by a distinct large blastocoel.

\section{Microsurgical bisection of pig embryos}

The microsurgical bisection was performed at room temperature using a micromanipulation unit consisting of an inverted microscope (Diavert, Leitz, Wetzlar) and a micromanipulator (Leitz, Wetzlar; Reichelt and Niemann, 1994). At $\times 100$ magnification and without a holding pipette, bisection was performed using a sterile microsurgical blade (Spezialklinge $S$, Heidelberg) with the embryo held in a droplet of $500 \mu \mathrm{l}$ PBS medium plus $10 \%(\mathrm{v} / \mathrm{v})$ NBCS. The embryo was fixed during bisection by scratches on the bottom of the plastic Petri dish made with the microblade. The microblade was held above the embryo placed between two scratches parallel to the blade. The zona pellucida and the embryo were divided into two pieces by slowly lowering the microblade. The inner cell mass of early blastocysts and blastocysts was carefully separated into two parts of similar size. Only one embryo was bisected per droplet of medium and each Petri dish contained three droplets of medium. To avoid an increase in medium osmolality, the three droplets of medium were changed after bisection of nine embryos, or every $20 \mathrm{~min}$. All demi-embryos were transferred into culture medium immediately after bisection.

\section{In vitro culture of demi-and intact embryos}

Intact embryos at the morula, early blastocyst or blastocyst stage were divided into three groups as controls. Embryos were fixed and stained (i) without culture $(0 \mathrm{~h})$; (ii) after $24 \mathrm{~h}$ of culture without zona pellucida and (iii) after $24 \mathrm{~h}$ of culture with zona pellucida. The zona pellucida was removed by a short-term incubation in $0.5 \%(w / v)$ pronase (Protease Type XXV, P-6911; Sigma) dissolved in PBS plus $1 \%(\mathrm{v} / \mathrm{v})$ NBCS. Culture in vitro was performed in a humidified atmosphere with $5 \% \mathrm{CO}_{2}$ in air at $37^{\circ} \mathrm{C}$. This culture temperature allows high rates of development under our laboratory conditions (Niemann and Elsaesser, 1987; Reichelt and Niemann, 1994). The culture medium was modified Krebs-Ringer-bicarbonate solution (mKRB) supplemented with $10 \%(\mathrm{v} / \mathrm{v})$ heat-inactivated lamb serum (Seromed, Berlin) and lacked lactate and pyruvate but contained EDTA (Saito and Niemann, 1991).

Only one pair of demi-embryos was cultivated per Petri dish containing $2 \mathrm{ml}$ of culture medium. After $24 \mathrm{~h}$ of culture, all halves were classified into three categories: 1 , excellent; 2 , fair; and 3, degenerated, leading to six possible combinations for the two halves of an embryo (Reichelt and Niemann, 1994). After $24 \mathrm{~h}$ of culture in vitro, demi-embryos and intact embryos (controls) were fixed and stained to count the number of inner cell mass and trophoblastic nuclei. Demi-embryos of categories 1 and 2 were subjected to the differential staining only if they had been derived from the combination $1 / 1,1 / 2$, or $2 / 2$, pairs considered as transferable (Reichelt and Niemann, 1994). Category 3 demi-embryos were evaluated irrespective of their partner.

\section{Generation of rabbit anti-pig antiserum}

A rabbit anti-pig antiserum was developed to apply an immunosurgical technique (SoIter and Knowles, 1975) to pig embryos, to make differential cell counts of the inner cell mass and trophoblastic cells of the embryo (Handyside and Hunter, 1984). Briefly, pieces of adult female pig spleen were minced, filtered and then washed in PBS $(2 \mathrm{~g}$ in $5 \mathrm{ml}$ ) and $1 \mathrm{ml}$ was injected s.c. into New Zealand White male rabbits. For immunization, the antigen was emulgated with Freund's adjuvant. Booster injections were given at 21, 35 and 49 days and the first blood sample was taken 10 days later. Further blood samples were collected at intervals of 2-3 weeks before each further booster injection. Serum was collected, heat inactivated $\left(50^{\circ} \mathrm{C}, 30 \mathrm{~min}\right)$ and tested for its efficiency to achieve 
immunosurgery. Serum with which immunosurgery could be achieved was used for the experiment.

\section{Double dye technique for differential inner cell mass and trophectoderm cell counts of demi-and intact pig embryos}

The procedure of Papaioannou and Ebert (1988) for the differential staining of inner cell mass and trophectoderm cells was carried out with minor modifications. Two chromatin specific fluorochromes with different fluorescent spectra were used with propidium iodide (Sigma Lot 33H3685), which is excluded from vital cells, and bisbenzimide (Hoechst 33258; Sigma), which can enter vital and nonvital cells. Intact embryos with a zona pellucida were treated with $0.5 \%(\mathrm{w} / \mathrm{v})$ pronase (Protease, Type XXV, P-6911; Sigma) in PBS plus $1 \%(\mathrm{v} / \mathrm{v})$ NBCS for 2 min to remove the zona pellucida. Zona pellucidafree intact and demi-embryos were incubated in PBS supplemented with $10 \%(\mathrm{v} / \mathrm{v})$ rabbit anti-pig antiserum for $15 \mathrm{~min}$ at $37^{\circ} \mathrm{C}$. Subsequently, embryos were briefly washed twice in warm $\left(37^{\circ} \mathrm{C}\right)$ PBS supplemented with $10 \%(\mathrm{v} / \mathrm{v}) \mathrm{NBCS}$ and then incubated in PBS medium plus $10 \%(\mathrm{v} / \mathrm{v})$ NBCS, $5 \%(\mathrm{v} / \mathrm{v})$ guinea pig complement and $10 \mu \mathrm{g}$ propidium iodide $\mathrm{ml}^{-1}$ for $13 \mathrm{~min}$ at room temperature. Embryos were then washed quickly in cold $\left(4^{\circ} \mathrm{C}\right) \mathrm{PBS}$ supplemented with $10 \mu \mathrm{g}$ propidium iodide $\mathrm{ml}^{-1}$ and in cold $\left(4^{\circ} \mathrm{C}\right)$ bisbenzimide $\left(10 \mu \mathrm{g} \mathrm{ml}^{-1}\right)$ ethanol solution. Subsequently, embryos were fixed in cold $\left(4^{\circ} \mathrm{C}\right)$ bisbenzimide $\left(10 \mu \mathrm{g} \mathrm{ml}{ }^{-1}\right)$ ethanol solution overnight. Finally, embryos were squashed on a slide and observed under a Nikon fluorescence microscope with an excitation filter of $365 \mathrm{~nm}$ and a barrier filter of $410 \mathrm{~nm}$. Inner cell mass cells could be recognized by the blue fluorescence of the Hoechst staining and trophectoderm cells by a red to pink fluorescence due to the accumulated propidium iodide.

\section{Statistical analyses}

Data were analysed by analysis of variance (SAS). Comparisons of data among developmental stages and the various morphological quality categories of demi-embryos were made by Multiple $t$ test (Tukey test). The number of demi-embryos with inner cell mass in the three different morphological categories was compared by chi-square test or Fisher's exact test, where appropriate. Differences were considered to be significant at $P<0.05$. Data are presented as means \pm SEM. Demi-embryos of categories 1 and 2 (transferable pairs) were evaluated for significant differences in the number of total and inner cell mass nuclei, dependent on the morphological category of the partner demi-embryo. As no significant differences could be detected, the data for demi-embryos in category 1 and 2 , respectively, were pooled to increase the number of observations per group and therefore the power of the statistical analysis.

\section{Results}

\section{General observations}

A total of 1268 ova and embryos was obtained from 41 donors, with an average of 34.2 corpora lutea per donor. The recovery rate was $91.0 \%$ (29.7 ova and embryos per donor).
Table 1. Distribution of embryos among the different treatment groups

\begin{tabular}{lcccc}
\hline & \multicolumn{3}{c}{ Intact embryos } & \\
\cline { 2 - 3 } Developmental stage & $\mathrm{oh}$ & $24 \mathrm{~h} \mathrm{ZP}+\quad 24 \mathrm{~h} \mathrm{ZP}-$ & $\begin{array}{c}\text { Embryos } \\
\text { bisected }\end{array}$ \\
\hline Morula & 67 & 56 & 51 & 177 \\
Early blastocyst & 36 & 43 & 38 & 76 \\
Blastocyst & 33 & 46 & 40 & 70 \\
\hline
\end{tabular}

$24 \mathrm{~h} \mathrm{ZP}+$, intact embryos were cultured with, and $\mathrm{ZP}-$ without zona pellucida for $24 \mathrm{~h}$.

Table 2. Inner cell mass and total number of cells ( \pm SEM) in pig embryos stained immediately after collection ( $\mathrm{h}$ controls)

\begin{tabular}{lccc}
\hline Parameter & Morula & Early blastocyst & Blastocyst \\
\hline $\begin{array}{l}\text { Number of embryos } \\
\text { Total cells }\end{array}$ & 61 & 35 & 27 \\
$\quad$ Number & $23.5 \pm 1.6$ & $47.1 \pm 3.0$ & $74.7 \pm 3.8$ \\
$\quad$ Range & $18-63$ & $14-104$ & $39-109$ \\
Inner cell mass & & & \\
$\quad$ Number & $7.0 \pm 0.5$ & $11.7 \pm 0.9$ & $16.4 \pm 1.2$ \\
$\quad$ Range & $0-18$ & $2-25$ & $5-28$ \\
Proportion (\%) & $31.7 \pm 2.0$ & $24.5 \pm 0.9$ & $22.0 \pm 1.2$ \\
& & & \\
\hline
\end{tabular}

Table 3. Classification of pairs of demi-embryos derived from morulae, early blastocysts and blastocysts after culture for $24 \mathrm{~h}$

\begin{tabular}{lrrrrrr}
\hline & \multicolumn{7}{c}{ Classification } \\
Developmental stage & $1 / 1$ & $1 / 2$ & $2 / 2$ & $1 / 3$ & $2 / 3$ & $3 / 3$ \\
\hline Morula & 34 & 39 & 25 & 31 & 27 & 21 \\
Early blastocyst & 22 & 19 & 8 & 11 & 10 & 6 \\
Blastocyst & 24 & 20 & 8 & 7 & 7 & 4 \\
\hline
\end{tabular}

Categories: 1, excellent; 2, fair; and 3, degenerated.

A total of 733 embryos (351 morulae, 193 early blastocysts and 189 blastocysts) were at the expected stage of development and possessed an intact morphology at the time of recovery. A total of 285 earlier developmental stages ( $2-8$ cell stages), as well as 250 unfertilized ova and degenerated embryos, were discarded.

The distribution of embryos among the different treatment groups is shown (Table 1). The majority of the 410 intact embryos (controls) could be analysed by the differential staining procedure ( 341 of $410 ; 83.2 \%$ ); $69(16.8 \%)$ were lost during the procedure. The results of the differential cell counts for the o h controls are given (Table 2).

The success of bisection of embryos in the three developmental stages is given (Table 3 ). The overall percentage success of transferable pairs was $61.6 \%$ (199 of 323). It was different $(P<0.05)$ among the three developmental stages $(55.4 \%$, $64.5 \%, 74.3 \%$ for morulae, early blastocysts and blastocysts, 

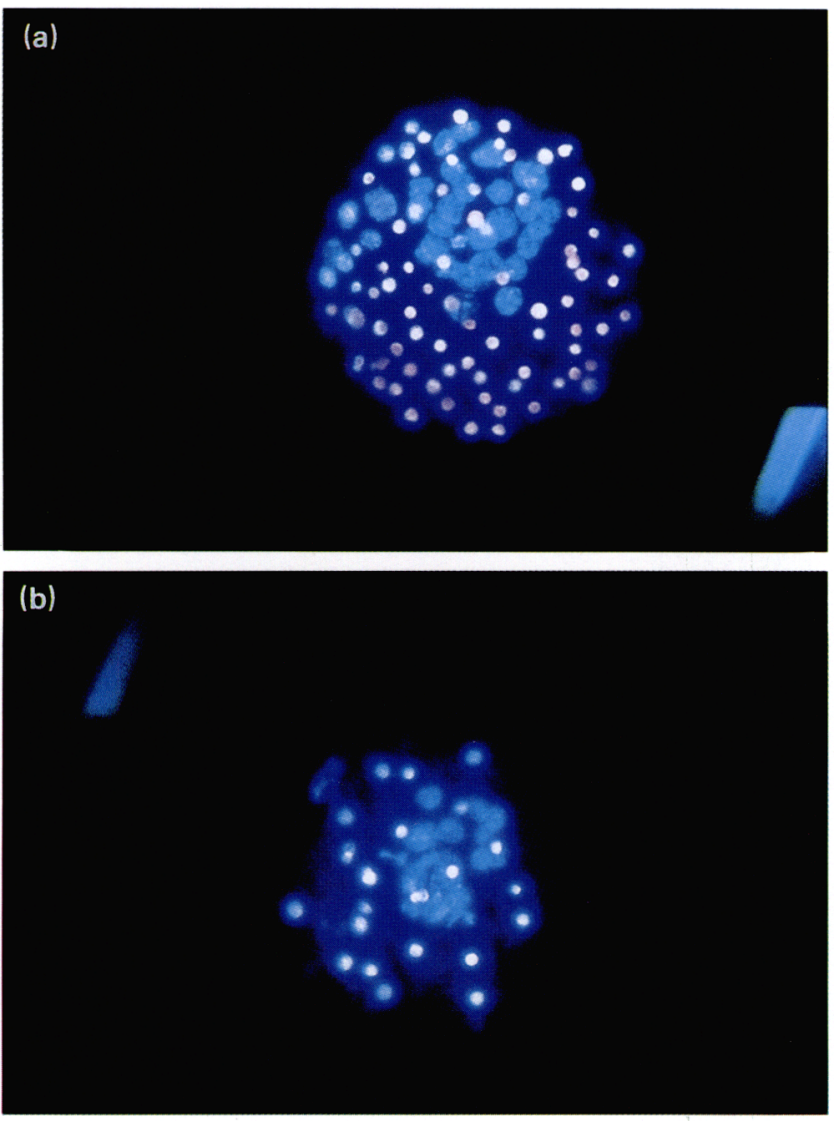

Fig. 1. (a) Differential staining of an intact zona pellucida-free pig embryo after culture in vitro for $24 \mathrm{~h}$. The embryo contains 28 inner cell mass cells, shown by the blue fluorescence, and 75 trophoblastic cells, shown by the pink colour. (b) Differential staining of a pig demi-embryo after $24 \mathrm{~h}$ of culture in vitro (category 2; fair). The demi-embryo contains 10 inner cell mass cells and 22 trophoblastic cells.

respectively). From the 466 demi-embryos taken for the double dye procedure, $405(86.9 \%)$ could be successfully analysed.

The double dye technique allowed a reliable and obvious distinction between the pink trophectoderm nuclei and intact inner cell mass cells in which the nuclei appear blue. The finding of at least one blue nucleus was taken as a measure for the presence of the inner cell mass. Examples of a differentially labelled demi-embryo and an intact nonbisected embryo are shown (Fig. 1). The number of total and inner cell mass cells was significantly lower in demi-embryos of the three morphological categories and derived from the three developmental stages compared with intact (control) embryos.

Frequency of the number of inner cell mass nuclei in demi-embryos

The frequency distribution of blue fluorescent nuclei in demi-embryos of the three morphological categories derived from the three developmental stages is shown (Fig. 2). The majority of category 1 demi-embryos bisected at the morula stage possessed I-4 inner cell mass nuclei. The majority of category 1 demi-embryos derived from early blastocysts and blastocysts had 5-8 inner cell mass nuclei. In morulae, the
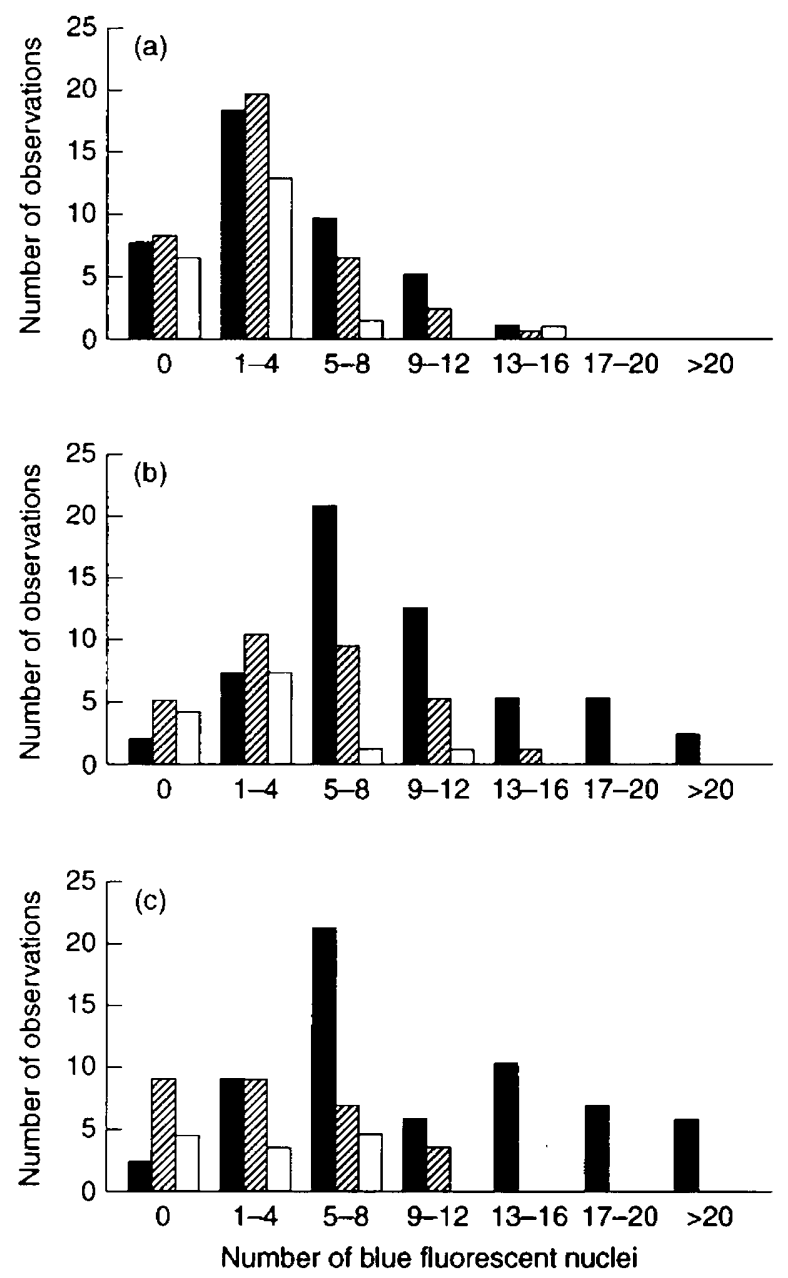

Fig. 2. Frequency distribution of blue fluorescent inner cell mass nuclei in categories 1 (excellent), 2 (fair) and 3 (degenerated) demi-embryos bisected at the (a) morula, (b) early blastocyst and (c) blastocyst stage. (回) category 1; (U) category 2; and ( $\square$ ) category 3. (a) category $1(n=91)$; category $2(n=81)$; category $3(n=47)$. (b) category 1 $(n=53)$; category $2(n=30)$; category $3(n=13)$. (c) category 1 $(n=54)$; category $2(n=25)$; category $3(n=10)$.

percentage of demi-embryos without an inner cell mass was not significantly different among the three morphological categories $(18.7 \%, 22.2 \%$ and $29.8 \%$, respectively). A lower $(P<0.01)$ percentage of demi-embryos from category 1 early blastocysts $(3.8 \%)$ did not possess an inner cell mass as compared with category $3(30.8 \%)$ demi-embryos (category 2 : $16.7 \%)$. In blastocysts, fewer $(P<0.01)$ category 1 demiembryos $(3.7 \%)$ did not contain an inner cell mass as compared with demi-embryos in categories 2 or $3(32.0 \%$ and $36.4 \%$, respectively).

Ratio of inner cell mass and trophoblastic cells in pig demi- or intact morulae

The average number of total and inner cell mass cells in pig morulae was 23.5 and 7.0 ( $0 \mathrm{~h}$ control), respectively (Table 2 ). Significant differences $(P<0.05)$ in the average number of inner cell mass and total cells were found between intact morulae 
Table 4. Number of total and inner cell mass cells (mean \pm SEM) in pig intact and demi-embryos bisected at the morula stage after culture for $24 \mathrm{~h}$ in vitro

\begin{tabular}{|c|c|c|c|c|c|c|}
\hline \multirow[b]{2}{*}{ Groups } & \multirow{2}{*}{$\begin{array}{l}\text { Number of } \\
\text { embryos }\end{array}$} & \multicolumn{2}{|c|}{ Total cells } & \multicolumn{3}{|c|}{ Inner cell mass* } \\
\hline & & Number & Range & Number of cells & Range & Proportion $(\%)$ \\
\hline \multicolumn{7}{|l|}{ Intact embryos } \\
\hline $24 \mathrm{~h} \mathrm{ZP}-{ }^{+}$ & 44 & $57.9 \pm 4.2^{\mathrm{a}}$ & $15-131$ & $11.8 \pm 0.9^{\mathrm{a}}$ & $2-29$ & $21.2 \pm 1.1$ \\
\hline $24 \mathrm{~h} \mathrm{ZP}^{+}$ & 48 & $32.9 \pm 2.8^{b}$ & $13-90$ & $7.7 \pm 0.7^{\mathrm{b}}$ & $2-22$ & $25.2 \pm 1.8$ \\
\hline \multicolumn{7}{|l|}{$\begin{array}{l}\text { Demi-embryo } \\
\text { categories }\end{array}$} \\
\hline I & 91 & $21.0 \pm 1.3^{c}$ & $5-59$ & $4.1 \pm 0.4^{c}$ & $0-14$ & $18.3 \pm 1.6$ \\
\hline $\begin{array}{l}1 \\
2\end{array}$ & 81 & $15.1 \pm 1.1^{\mathrm{cd}}$ & $2-39$ & $3.0 \pm 0.4^{\mathrm{c}}$ & $0-14$ & $21.6 \pm 2.5$ \\
\hline 3 & 47 & $11.3 \pm 1.1^{\mathrm{d}}$ & $2-32$ & $2.1 \pm 0.4^{c}$ & $0-14$ & $18.6 \pm 0.4$ \\
\hline
\end{tabular}

*At least one inner cell mass cell was detected as indicated by blue fluorescence.

${ }^{\dagger} 24 \mathrm{~h} \mathrm{ZP}+$ and ZP - : intact embryos were cultured with and without zona pellucida, respectively, for $24 \mathrm{~h}$.

${ }^{\text {abcd }}$ Values with different superscript letters are significantly different $(P<0.05)$.

Table 5. Number of total and inner cell mass cells (mean \pm SEM) in pig intact and demi-embryos bisected at the early blastocyst stage after culture for $24 \mathrm{~h}$ in vitro

\begin{tabular}{|c|c|c|c|c|c|c|}
\hline \multirow[b]{2}{*}{ Groups } & \multirow{2}{*}{$\begin{array}{c}\text { Number of } \\
\text { embryos }\end{array}$} & \multicolumn{2}{|c|}{ Total cells } & \multicolumn{3}{|c|}{ Inner cell mass* } \\
\hline & & Number & Range & Number of cells & Range & Proportion (\%) \\
\hline \multicolumn{7}{|l|}{ Intact embryos } \\
\hline $24 \mathrm{~h} \mathrm{ZP}-{ }^{\dagger}$ & 33 & $96.0 \pm 4.9^{a}$ & $36-163$ & $18.1 \pm 1.1^{\mathrm{a}}$ & $4-32$ & $19.0 \pm 0.8$ \\
\hline $24 \mathrm{~h} \mathrm{ZP}+{ }^{\dagger}$ & 32 & $80.8 \pm 3.4^{\mathrm{b}}$ & $39-106$ & $17.3 \pm 0.9^{\mathrm{a}}$ & $6-30$ & $22.3 \pm 1.4$ \\
\hline \multicolumn{7}{|l|}{$\begin{array}{l}\text { Demi-embryo } \\
\text { categories }\end{array}$} \\
\hline 1 & 53 & $35.3 \pm 1.3^{\mathrm{c}}$ & $18-61$ & $9.3 \pm 0.8^{b}$ & $0-26$ & $26.5 \pm 2.3$ \\
\hline 2 & 30 & $27.3 \pm 2.0^{\mathrm{cd}}$ & $11-58$ & $4.9 \pm 0.7^{\mathrm{c}}$ & $0-14$ & $17.5 \pm 2.3$ \\
\hline 3 & 13 & $17.2 \pm 1.9^{\mathrm{d}}$ & $8-32$ & $2.7 \pm 0.9^{\mathrm{d}}$ & $0-11$ & $15.3 \pm 4.9$ \\
\hline
\end{tabular}

*At least one inner cell mass cell was detected as indicated by blue fluorescence.

${ }^{\dagger} 24 \mathrm{~h} \mathrm{ZP}+$ and ZP - : intact embryos were cultured with and without zona pellucida, respectively, for $24 \mathrm{~h}$.

abcd Values with different superscript letters are significantly different $(P<0.05)$.

with and without zona pellucida after $24 \mathrm{~h}$ culture (Table 4 ). The statistical analysis revealed no significant differences in the number of inner cell mass cells among the different categories of demi-embryos. In the total cell number a significant $(P<0.05)$ difference was observed between categories 1 and 3. The proportion of inner cell mass to the total number of cells was not different among the various categories of intact and morula derived demi-embryos (Table 4). However, this proportion was different $(P<0.05)$ between 0 h controls and all other groups.

Ratio of inner cell mass and trophoblastic cells in pig demi- or intact early blastocysts

The average number of total and inner cell mass cells in pig early blastocysts was 47.1 and 11.7 ( $0 \mathrm{~h}$ controls), respectively. The difference in total cell numbers between intact early blastocysts with and without zona pellucida after $24 \mathrm{~h}$ culture (80.8 and 96.0, respectively) was significant $(P<0.05)$ (Table $5)$. The total number of cells was different between demi- embryos in categories 1 and $3(P<0.05)$. The number of inner cell mass cells was higher in category I demi-embryos compared with demi-embryos in categories 2 and $3(P<0.05)$. There were no significant differences in the proportion of inner cell mass to the total number of cells among the various categories of early blastocyst demi- and intact embryos (Table 5).

Ratio of inner cell mass and trophoblastic cells in pig demi- and intact blastocysts

The average number of total and inner cell mass cells in pig blastocysts was 74.7 and 16.4 ( $0 \mathrm{~h}$ control), respectively. The average number of inner cell mass and total cells in control blastocysts without zona pellucida cultured for $24 \mathrm{~h}$ was similar to that for those with zona pellucida (Table 6). The number of inner cell mass cells in demi-embryos of category 1 was higher than in categories 2 and $3(P<0.05)$. The total number of cells was different between demi-embryos classified in categories 1 and $3(P<0.05)$. There were no significant differences in the 
Table 6. Number of total and inner cell mass cells (mean \pm SEM) in pig intact and demi-embryos bisected at the blastocyst stage after culture for $24 \mathrm{~h}$ in vitro

\begin{tabular}{|c|c|c|c|c|c|c|}
\hline \multirow[b]{2}{*}{ Groups } & \multirow{2}{*}{$\begin{array}{c}\text { Number of } \\
\text { embryos }\end{array}$} & \multicolumn{2}{|c|}{ Total cells } & \multicolumn{3}{|c|}{ Inner cell mass* } \\
\hline & & Number & Range & Number of cells & Range & Proportion (\%) \\
\hline \multicolumn{7}{|l|}{ Intact embryos } \\
\hline $24 \mathrm{~h} \mathrm{ZP}^{+}$ & 31 & $107.3 \pm 3.5^{a}$ & $67-151$ & $21.1 \pm 1.2^{\mathrm{a}}$ & $7-34$ & $19.8 \pm 1.1^{b}$ \\
\hline $24 \mathrm{~h} \mathrm{ZP}+^{+}$ & 30 & $98.3 \pm 3.0^{\mathrm{a}}$ & $65-130$ & $17.7 \pm 1.0^{\mathrm{a}}$ & $9-28$ & $18.1 \pm 0.9^{b}$ \\
\hline \multicolumn{7}{|l|}{$\begin{array}{l}\text { Demi-embryo } \\
\text { categories }\end{array}$} \\
\hline 1 & 54 & $35.9 \pm 1.2^{b}$ & $18-53$ & $10.6 \pm 1.0^{b}$ & $0-33$ & $32.9 \pm 3.6^{\mathrm{a}}$ \\
\hline 2 & 25 & $26.1 \pm 1.5^{\mathrm{bc}}$ & $16-41$ & $3.4 \pm 0.7^{\mathrm{c}}$ & $0-10$ & $11.8 \pm 2.5^{\mathrm{b}}$ \\
\hline 3 & 11 & $18.4 \pm 2.8^{\mathrm{c}}$ & $5-35$ & $2.8 \pm 0.8^{c}$ & $0-7$ & $13.2 \pm 3.4^{b}$ \\
\hline
\end{tabular}

*At least one inner cell mass cell was detected as indicated by blue fluorescence.

${ }^{\dagger} 24 \mathrm{~h} \mathrm{ZP}+$ and $\mathrm{ZP}-$ : intact embryos were cultured with and without zona pellucida, respectively, for $24 \mathrm{~h}$.

abc Values with different superscript letters are significantly different $(P<0.05)$.

Table 7. Effect of bisection at different embryonic stages on cell losses in relation to quality of demi-embryos after culture for $24 \mathrm{~h}$ in vitro

\begin{tabular}{|c|c|c|c|c|c|}
\hline \multirow[b]{2}{*}{ Categories of demi-embryos } & \multirow{2}{*}{$\begin{array}{c}\text { Number of } \\
\text { embryos }\end{array}$} & \multicolumn{2}{|c|}{ Number of total cells } & \multicolumn{2}{|c|}{ Number of inner cell mass cells } \\
\hline & & Mean* & Losses $(\%)^{\dagger}$ & Mean* & Losses $(\%)^{\dagger}$ \\
\hline \multicolumn{6}{|l|}{ Morula } \\
\hline Controls & 44 & 57.9 & - & 11.8 & - \\
\hline 1 & 91 & 42.1 & 27.3 & 8.3 & 26.7 \\
\hline 2 & 81 & 30.1 & 47.8 & 6.0 & 49.2 \\
\hline 3 & 47 & 22.6 & 61.0 & 4.3 & 63.6 \\
\hline \multicolumn{6}{|l|}{ Early blastocyst } \\
\hline Controls ${ }^{\ddagger}$ & 33 & 96.0 & - & 18.1 & - \\
\hline $\mathrm{I}$ & 53 & 70.6 & 26.5 & 18.6 & 0 \\
\hline 2 & 30 & 54.5 & 43.2 & 9.9 & 45.3 \\
\hline 3 & 13 & 34.3 & 64.3 & 5.4 & 70.2 \\
\hline \multicolumn{6}{|l|}{ Blastocyst } \\
\hline Controls $^{\ddagger}$ & 32 & 107.3 & - & 21.1 & - \\
\hline 1 & 54 & 71.8 & 33.1 & 21.1 & 0 \\
\hline 2 & 25 & 52.2 & 51.4 & 6.8 & 68.2 \\
\hline 3 & 11 & 36.7 & 65.8 & 5.6 & 73.5 \\
\hline
\end{tabular}

*For demi-embryos: mean of total cells and inner cell mass cell number multiplied by 2 .

${ }^{+}$The loss of cells was calculated on the basis of the difference between the number of total and inner cell mass cells in controls and double the number of total and inner cell mass cells in demi-embryos.

"Intact embryos were cultured without zona pellucida for $24 \mathrm{~h}$ in vitro.

proportion of inner cell mass to the total number of cells among the different categories of blastocyst demi- and intact embryos, with the exception of the differences between category 1 demi-embryos and the other groups (Table 6).

\section{Losses of total and inner cell mass cells during the bisection process}

The effects of bisection on cell losses in relation to the quality of demi-embryos are shown (Table 7). The theoretical percentage of cell losses in demi-embryos attributed to bisection was calculated on the basis of the difference between the mean of total and inner cell mass cells of the zona-free controls and double the mean of total and inner cell mass cells of demi-embryos after $24 \mathrm{~h}$ in vitro. According to the theoretical calculation, in category 1 demi-embryos derived from early blastocysts and blastocysts, no inner cell mass cells were lost, and these demi-embryos had undergone a 26.5\%-33.1\% reduction of trophoblastic cells (Table 7).

\section{Discussion}

The present study is the first to describe the frequency of demi-embryos with an inner cell mass; and the ratio of inner cell mass to trophoblastic cells, compared with those in zona pellucida-free and enclosed nonbisected embryos. The 
differential staining procedure used to identify inner cell mass and trophoblastic cells was successfully used in mouse (Handyside, 1981; Handyside and Hunter, 1984), pig (Papaioannou and Ebert, 1988; Boerjan and Kronnie, 1993), frozen-thawed bovine and pig embryos (Iwasaki et al., 1994a,b) and in vitro produced bovine embryos (Iwasaki et al., 1990). In our study, the technique proved useful for investigating the presence and ratio of total to inner cell mass cells in pig intact and demi-embryos after culture in vitro.

There is a considerable overlap in numbers of cells among the different developmental stages in the controls fixed at the time of bisection ( $0 \mathrm{~h}$ controls), which reflects biological variation in embryo development (Papaioannou and Ebert, 1988; Boerjan and Kronnie, 1993). In pigs, blastocyst formation usually begins after the fourth cell cycle (Papaioannou and Ebert, 1988), which is confirmed by our data. However, blastocoel formation was observed in one embryo with 14 cells, and 11 embryos classified as morulae possessed 32 cells.

In mice, there are conflicting results about when inner cells are protected from complement-mediated lysis due to the formation of functional tight junctions. This time point is reported at the 32-cell stage (McLaren and Smith, 1977; Handyside, 1978), and during the fourth cell cycle (Handyside, 1981), which corresponds to our results in pigs. Further investigations are required to determine the time of formation of functional tight junctions in pig embryos more accurately. Furthermore, the data from the $\mathrm{oh}$ control embryos showed that the total number of cells and the proportion of inner cell mass cells are sufficient, in all three developmental stages tested, to generate a high number of transferable pairs after bisection.

The number of cells in pig intact morulae and early blastocysts cultured without zonae pellucidae for $24 \mathrm{~h}$ was higher than that for those with an intact zona pellucida, while it was not different in blastocysts. This substantiates an earlier suggestion that the zona pellucida regulates cell division in early stage embryos (Niemann et al., 1983b). As the time of the shedding of the zona pellucida approaches, its role in regulating cell division obviously becomes less significant. Further studies are necessary to elucidate the mechanism of this regulatory effect of the zona pellucida. As the present results demonstrate that intact embryos without zona pellucida developed faster than those with a zona pellucida, it is preferable not to place demi-embryos from morulae and early blastocysts into surrogate zonae pellucidae. This conclusion is supported by the high pregnancy rates $(81.5 \%)$ following transfer of zona-free pig demi-embryos after $24 \mathrm{~h}$ of culture in vitro (Reichelt and Niemann, 1994). Similarly, the transfer of zona pellucida-free bovine demi-embryos derived from morulae results in high (73\%) pregnancy rates (Seike et al., 1989).

The results presented here clearly show that the bisection of early blastocysts and blastocysts results in a high frequency of demi-embryos in category 1 having an inner cell mass consisting of more than four cells. The presence of an inner cell mass seems to be correlated with the quality score, as with decreasing quality the frequency of demi-embryos with more than four inner cell mass cells declined. Wurth et al. (1988) showed that the mean number of cells in bovine blastocysts recovered in vivo decreased with decreasing morphological quality. In contrast, bisection of morulae resulted in a high proportion of demi-embryos after $24 \mathrm{~h}$ of culture without inner cell mass cells. The reduced litter size and at least some of the failures to obtain pregnancies after transfer of demi-embryos could therefore be attributed to a lack of an inner cell mass in a considerable proportion of the demi-embryos. The results of this study indicate that the blastocyst is the most appropriate stage for bisection of pig embryos. The morphology of the blastocyst allows easy access to the inner cell mass, and it is easier to divide the inner cell mass and trophoblast layer into two equal parts in blastocysts than it is to generate viable demi-embryos from morulae.

The establishment of effective communication between embryo and uterus after transfer of demi-embryos depends on the number and quality of embryonic cells (Heyman, 1985). The trophoblastic cells are specialized for the vectorial transport of fluid during blastocyst formation and later for the attachment and invasion of the uterine endometrium during implantation. The survival of the transferred embryo depends mainly on the undisturbed viability of the inner cell mass, which gives rise to the embryo proper (Gardner et al., 1973). In the present study, the numbers of inner cell mass and total cells were significantly different among the three morphological categories. This indicates that the classification system used to identify transferable demi-embryos after $24 \mathrm{~h}$ culture (Reichelt and Niemann, 1994) was reliable.

The proportion of cells that stain like the inner cell mass in intact pig embryos decreased gradually with advancement from the morula to the blastocyst stage. This suggests that the growth of the inner cell mass slowed relative to the growth of the trophectoderm, and supports the observation that pig trophectoderm continues rapid growth while that of the inner cell mass slows down between the expanded and hatched blastocyst stage (Papaioannou and Ebert, 1988). However, it has not yet been determined whether this represents a slowing down in cell division rate or a contribution of inner cell mass cells to the trophectoderm, as observed in mouse embryos (Copp, 1978; Handyside and Hunter, 1986).

Among intact pig embryos $(24 \mathrm{~h}$ controls with and without zona pellucida) and the different categories of demi-embryos derived from morulae, early blastocysts and blastocysts, the proportion of inner cell mass to the total number of cells was similar except between category I demi-embryos and the other groups. This finding shows that the bisection procedure in general did not alter the normal proportion of inner cell mass to total cells in demi-embryos, which could be an explanation for the high pregnancy rate obtained after transfer at this stage (Reichelt and Niemann, 1994). Willadsen and Polge (1981) demonstrated that a reduced proportion of the inner cell mass led to decreased viability. In the present study, although bisection in general did not alter the ratio of inner cell mass to trophoblastic cells, the bisection process was associated with the loss of a substantial percentage of cells which gradually increases with decreasing quality of the resulting demi-embryo. This loss, which affected inner cell mass and trophoblastic cells differently, was similar in all three developmental stages and was higher than that reported by Skrzyszowska and Smorag (1989). However, the average category 1 demi-embryo derived from early blastocysts and blastocysts was characterized by no loss of the inner cell mass cells, which indicates optimal splitting or considerable potential for compensatory growth 
potential in vitro. A substantial percentage of demi-embryos with few cells would be unable to undergo normal fetal development and consequently litter size would be expected to be reduced, as shown recently by Reichelt and Niemann (1994).

In conclusion, the splitting procedure used in this study did not alter the normal proportion of inner cell mass to total cells in demi-embryos, when compared with that of intact embryos. However, a substantial percentage of demi-embryos derived from morulae and (early) blastocysts did not contain an inner cell mass (categories 2 and 3), partly explaining the high embryonic losses upon transfer of porcine demi-embryos. Therefore, the blastocyst is the most appropriate stage for bisection. The study of the proportion of inner cell mass to trophectoderm cells using the differential staining technique could prove useful for embryos subjected to various manipulative procedures. Extended culture and nuclear transfer in vitro could alter the ratio of inner cell mass to trophoblastic cells. Transfer of such manipulated embryos has led to abnormalities in the duration of gestation and birth mass in sheep and cattle, with severe effects on postnatal survival (Willadsen et al., 1991; Walker et al., 1992).

T. Tao is a visitor from the Institute of Animal Science (CAAS), Beijing 100094, P.R. China. The financial support for T. Tao and B. Reichelt from the Deutsche Forschungsgemeinschaft (SFB 330) is gratefully acknowledged. The authors thank F. Klobasa (Institut für Tierzucht und Tierverhalten) for the preparation of the antiserum.

\section{References}

Ash K, Anderson GB, BonDurant RH, Pashen RL, Parker KM and Berger T (1989) Competition between split and nonmanipulated embryos in the production of identical piglets Theriogenology $31903-910$

Baker RD and Shea BF (1985) Commercial splitting of bovine embryos Theriogenology 23 3-12

Boerjan ML and Kronnie GT (1993) The segregation of inner and outer cells in porcine embryos follows different pattern to the segregation in mouse embryos Roux's Archives Developmental Biology 203 113-116

Copp AJ (1978) Interaction between inner cell mass and trophectoderm of the mouse blastocyst. I. A study of cellular proliferation Journal of Embryology and Experimental Morphology 48 109-125

Gardner RL, Papaioannou VE and Barton SC (1973) Origin of the ectoplacental cone and secondary giant cells in mouse blastocysts reconstituted from isolated trophoblast and inner cell mass Journal of Embryology and Experimental Morphology 30 561-572

Gray KR, Bondioli KR and Betts CL (1991) The commercial application of embryo splitting in beef cattle. Theriogenology 35 45-54

Handyside AH (1978) Time of commitment of inside cells isolated from preimplantation mouse embryos Journal of Embryology and Experimental Morphology 45 37-53

Handyside AH (1981) Immunofluorescence techniques for determining the numbers of inner and outer blastomeres in mouse morulae Journal of Reproductive Immunology 2 339-350

Handyside AH and Hunter S (1984) A rapid procedure for visualising the inner cell mass and trophectoderm nuclei of mouse blastocysts in situ using polynucleotide-specific fluorochromes Journal of Experimental Zoology 231 429-434

Handyside AH and Hunter S (1986) Cell division and death in the mouse blastocyst before implantation Roux's Archives Developmental Biology 195 $519-526$

Heyman Y (1985) Factors affecting the survival of whole and half embryos transferred in cattle Theriogenology 23 63-75
Iwasaki S, Yoshiba N, Ushijima H, Watanabe S and Nakahara T (1990) Morphology and proportion of inner cell mass of bovine blastocysts fertilized in vitro and in vivo Journal of Reproduction and Fertility 90 279-284

Iwasaki S, Yoshikane Y, Li X, Watanabe S and Nakahara T (1994a) Effects of freezing of bovine preimplantation embryos derived from oocytes fertilized in vitro on survival of their inner cell mass cells Molecular Reproduction and Development 37 272-275

Iwasaki S, Mizuno J, Kolayashi K, Yoshikane Y and Hayashi T (1994b) Changes in morphology and cell number of inner cell mass of porcine blastocysts during freezing Theriogenology 42 841-848

Kippax I, Christie W and Rowan TG (1991) Effects of methods of splitting, stage development and presence or absence of zona pellucida on fetal survival in commercial bovine embryo transfer of bisected embryos Theriogenology 35 25-35

McLaren A and Smith R (1977) Functional test of tight junctions in the mouse blastocyst Nature $267351-357$

Nagashima H, Katoh J, Shibata K and Ogawa S (1988) Production of normal piglets from microsurgically split morulae and blastocysts Theriogenology 29 485-495

Nagashima H, Kato Y and Ogawa S (1989) Microsurgical bisection of porcine morulae and blastocysts to produce monozygotic twin pregnancy Gamete Research 23 1-9

Niemann H and Elsaesser F (1987) Steroid hormones in early pig embryo development. In The Mammalian Preimplantation Embryo: Regulation of Growth and Development pp 117-132 Ed. BD Bavister. Plenum Press, New York

Niemann H and Reichelt B (1993) Manipulating early pig embryos Journal of Reproduction and Fertility Supplement 48 75-94

Niemann H, Illera MJ and Dziuk PJ (1983a) Developmental capacity, size and number of nuclei in pig embryos cultured in vitro Animal Reproduction Science $5311-321$

Niemann H, Illera MJ and Smidt D (1983b) In vitro development of pig morulae after enzymatic removal or microsurgical treatment of the zona pellucida Theriogenology 19142 (abstract)

Papaioannou VE and Ebert KM (1988) The preimplantation pig embryo: cell number and allocation to trophectoderm and inner cell mass of the blastocyst in vivo and in vitro Development 102 793-803

Reichelt B and Niemann H (1994) Generation of identical twin piglets following bisection of embryos at the morula and blastocyst stage journal of Reproduction and Fertility 100 163-172

Saito S and Niemann H (1991) Effects of extracellular matrices and growth factors on the development of isolated porcine blastomeres Biology of Reproduction 44 927-936

Seike N, Saeki K, Utaka K, Sakai M, Takakura R, Nagao Y and Kanagawa H (1989) Production of bovine identical twins via transfer of demi-embryos without zonae pellucidae Theriogenology 32 211-220

Skrzyszowska M and Smorag Z (1989) Cell loss in bisected mouse, sheep and cow embryos Theriogenology 32 115-122

Solter D and Knowles BB (1975) Immunosurgery of mouse blastocyst Proceedings National Academy of Sciences USA 72 5099-5102

Stein-Stefani J and Holtz W (1994) Splitting of porcine embryos at the four-cell or morula stage Theriogenology 41 961-968

Takeda T, Hallowell SV, McCauley AP and Hasler JF (1986) Pregnancy rates with intact and split embryos transferred surgically and nonsurgically Theriogenol ogy 25205 (Abstract)

Walker SK, Heard TM and Seamark RF (1992) in vitro culture of sheep embryos without coculture: success and perspectives Theriogenology 37 III-126

Willadsen SM and Polge C (1981) Attempts to produce monozygotic quadruplets in cattle by blastomere separation Veterinary Record 108 211-213

Willadsen SM, Janzen ZRG, McAlister RJ, Shea BF, Hamilton G and McDermand D (1991) The viability of late morulae and blastocysts produced by nuclear transplantation in cattle Theriogenology 35 161-170

Williams TJ, Elsden RP and Seidel GE, Jr (1984) Pregnancy rates with bisected bovine embryos Theriogenology 22 521-531

Wurth YA, van der Zee-Kotting W, Kruip ThA, Dieleman SJ and Bevers MM (1988) Relation between macroscopic qualification of bovine embryos and number of blastomeres Proceedings 11th International Congress Animal Reproduction and AI, Dublin, Vol. 3 No. 352 